\title{
WINGLESS (WNT) signaling is a progesterone target for rat uterine stromal cell proliferation
}

\author{
Virginia Rider1, Alex Talbott1, Anuradha Bhusri1, Zach Krumsick', Sierra Foster', \\ Joshua Wormington' ${ }^{1}$ and Bruce F Kimler \\ 1Department of Biology, Pittsburg State University, Pittsburg, Kansas, USA \\ 2Department of Radiation Oncology, The University of Kansas Medical Center, Kansas City, Kansas, USA
}

Correspondence should be addressed to $\mathrm{V}$ Rider

Email

vrider@pittstate.edu

\begin{abstract}
Preparation of mammalian uterus for embryo implantation requires a precise sequence of cell proliferation. In rodent uterus, estradiol stimulates proliferation of epithelial cells. Progesterone operates as a molecular switch and redirects proliferation to the stroma by down-regulating glycogen synthase kinase-3 $\beta$ (GSK-3 $\beta$ ) and stimulating $\beta$-catenin accumulation in the periluminal stromal cells. In this study, the WNT signal involved in the progesterone-dependent proliferative switch was investigated. Transcripts of four candidate Wnt genes were measured in the uteri from ovariectomized (OVX) rats, progesterone-pretreated (3 days of progesterone, $2 \mathrm{mg} /$ daily) rats, and progesterone-pretreated rats given a single dose $(0.2 \mu \mathrm{g})$ of estradiol. The spatial distribution of the WNT proteins was determined in the uteri after the same treatments. Wnt5a increased in response to progesterone and the protein emerged in the periluminal stromal cells of progesterone-pretreated rat uteri. To investigate whether WNT5A was required for proliferation, uterine stromal cell lines were stimulated with progesterone $(1 \mu \mathrm{M})$ and fibroblast growth factor (FGF, $50 \mathrm{ng} / \mathrm{mL})$. Proliferating stromal cells expressed a two-fold increase in WNT5A protein at $12 \mathrm{~h}$ post stimulation. Stimulated stromal cells were cultured with actinomycin D $(25 \mu \mathrm{g} / \mathrm{mL})$ to inhibit new RNA synthesis. Relative Wnt5a expression increased at 4 and $6 \mathrm{~h}$ of culture, suggesting that progesterone plus FGF preferentially increased Wnt5a mRNA stability. Knockdown of Wnt5a in uterine stromal cell lines inhibited stromal cell proliferation and decreased Wnt5a mRNA. The results indicate that progesterone initiates and synchronizes uterine stromal cell proliferation by increasing WNT5A expression and signaling.
\end{abstract}

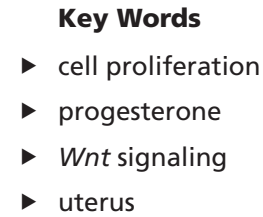

Journal of Endocrinology (2016) 229, 197-207

\section{Introduction}

In adult female mammals, the uterus undergoes remodeling with a regular cyclicity under the control of the sex hormones, progesterone and estradiol (Bell 1983, Pawar et al. 2014). In the rodent uterus, estradiol stimulates the proliferation of luminal and glandular epithelial cells at days 2 and 3 post-coitum (Finn \& Martin 1967). At day 4 of pregnancy in rats, cell division switches from the luminal and glandular epithelium to the endometrial stroma in 
response to progesterone (Rider \& Psychoyos 1994). Stromal cells proliferate and differentiate to form the maternal tissue referred to as the decidua that interfaces with the fetal placenta. Differentiation of stromal cells is accompanied by an increase in cell size, polyploidization, and changes in gene expression including increased expression of decidual prolactin, IGF-binding protein 1 (IGFBP1) and fibroblast growth factor (FGF). Mice lacking genes that control decidualization cannot maintain pregnancy (Laws et al. 2008, Wang et al. 2013).

WNT glycoproteins comprise a family of at least 19 ligands that bind to G-protein-coupled frizzled receptors and two low-density lipoprotein receptor-related protein co-receptors (Paul \& Dey 2008, Sonderegger et al. 2010, Tepekoy et al. 2015). WNT signaling is required for proper development of the mammalian female reproductive tract (Parr \& McMahon 1998). Female mice that lack WNT5A by targeted deletion do not develop posterior reproductive tract structures (Mericskay et al. 2004). WNT5A and WNT7A are required for proper uterine gland formation (Dunlap et al. 2011, Hayashi et al. 2011). WNT4 deficiency in humans results in the insufficient formation of the Mullerian duct of the female reproductive tract (Philibert et al. 2008). WNT4-deficient females develop Wolffian ducts owing to the production of testosterone in mice lacking WNT4 (Vainio et al. 1999).

Less is known about the integration of WNT signaling in the adult uterus, although changes in the spatial and temporal expression of $W n t$ genes during the implantation period suggest their importance in the establishment of pregnancy (Mohamed et al. 2005, Sonderegger et al. 2010, Hayashi et al. 2011, Fritz et al. 2014). The Wnt/ $\beta$-catenin pathway plays a critical function at the site of implantation as inhibition of this signaling pathway interferes with the process (Mohamed et al. 2005). Several WNT proteins (WNT4, WNT5A, WNT6, and WNT7A) are highly expressed in the adult uterus (Hayashi et al. 2011, Li et al. 2013, Wang et al. 2013). Ablation of Wnt4 in the adult mouse uterus leads to hypertrophy of the luminal epithelium and implantation failure (Franco et al. 2011). Inactivation of Wnt5a in adult mouse uteri has resulted in compromised fertility, whereas overexpression of the protein has decreased litter size (Cha et al. 2014). The results from the study (Cha et al. 2014) suggests that decidualization requires WNT5A in the appropriate amounts for decidualization and normal pregnancy. Wht6null mutant mice show a reduction in litter size (Wang et al. 2013). Interestingly, embryo attachment appeared normal in the absence of Wnt6; however, at days 6-7 of pregnancy, the weight and size of implantation sites had declined. Wnt7a-knockout mice do not express Hoxa10 and Hoxa11 in the endometrial stroma and stromal cell differentiation fails and infertility ensues (Miller \& Sassoon 1998). Postnatal deletion of Wnt7a diminishes the formation of uterine glands. The number of embryos recovered from the uteri of the mutant mice, however, was not different from wild-type mice, indicating that implantation failed in the mutants rather than an ovulation or embryo defect (Dunlap et al. 2011).

Although ablation of various Wnt genes has established their importance in embryo-maternal interactions, Wnt signal transduction mechanisms in the different reproductive cell types is not well understood. In the uteri of adult mammals, female sex steroids direct changes that alter the uterus from a hostile to a receptive state for embryo implantation (Franco et al. 2012, Fritz et al. 2014, Pawar et al. 2014). Hormones stimulate uterine cell proliferation by a variety of mechanisms, including the induction of growth factors/growth factor receptors and paracrine signaling, and by direct regulation of cell cycle genes (Jones et al. 2000, Yao et al. 2003, Butt et al. 2008). In the rodent uterus, estradiol stimulates epithelial cell proliferation, whereas progesterone redirects proliferation from the epithelial to the stromal compartment. Administration of progesterone to ovariectomized (OVX) rats for three consecutive days increases the number of proliferating stromal cells approximately five-fold (Rider \& Psychoyos 1994). This proliferative switch is accompanied by decreased GSK-3ß expression in progesterone-pretreated uterine stromal cells and increased accumulation of $\beta$-catenin (Rider et al. 2006). $\beta$-catenin is a transcriptional regulator that interacts with T-cell factor (TCF/lymphoid enhancer factor (LEF)) and converts the TCF/LEF repressor complex into a transcriptional activator (Daniels \& Weis 2005, Willert \& Jones 2006). Progesterone stimulates the accumulation of $\beta$-catenin in the uterine stromal cells, whereas estradiol stimulates its nuclear translocation. Nuclear $\beta$-catenin increases complex formation with LEF and activates Wnt target genes (Rider et al. 2006). Targeted disruption of normal $\beta$-catenin regulation results in infertility, and the uteri in mutant mice cannot undergo the decidual reaction (Jeong et al. 2009).

In this study, we have extended our earlier observations in order to identify the endocrine-responsive Wnt gene(s) involved in stromal cell proliferation. Wnt5a expression increased in progesterone-pretreated rat uteri and the protein localized to the presumptive decidual cells. Stromal cell lines stimulated with progesterone and FGF exhibited an increase in cell number and a two-fold increase in WNT5A protein. Addition of actinomycin D to inhibit Wnt5a

Published by Bioscientifica Ltd. 
expression did not reduce Wnt5a transcripts, suggesting that progesterone plus FGF enhances expression, in part, by stabilizing Wnt5a mRNA. Knockdown of Wnt5a mRNA in proliferating stromal cells decreased $W n t 5 a$ expression and blocked progesterone-dependent proliferation.

\section{Materials and methods}

\section{Animals and hormone treatments}

Sexually mature (150-175 g body weight) Sprague-Dawley rats (Charles River Laboratories) were bilaterally OVX and rested for 10 days. Rats were housed on a $14 \mathrm{~h}$ light: $10 \mathrm{~h}$ darkness cycle at the Pittsburg State University and provided rodent chow and water ad libitum. Animals were treated in accordance with the principles and procedures outlined in the NIH Guidelines for the Care and Use of Experimental Animals. The Pittsburg State University Animal Care Committee approved protocols for the care and the use of rats. To stimulate stromal cell proliferation, OVX rats were injected subcutaneously (s.c.) with progesterone $(2 \mathrm{mg}$; Sigma-Aldrich) and dissolved in sesame oil daily for three consecutive days. On the fourth day, estradiol $17-\beta(0.2 \mu \mathrm{g}$; Sigma-Aldrich) was injected s.c. This hormone regimen increases the number of synchronously proliferating stromal cells three- to five-fold compared with normally pregnant animals (Rider \& Psychoyos 1994). The uterine horns were removed at $6 \mathrm{~h}$ post estradiol injection when a significant number of stromal cells are in $\mathrm{S}$ phase of the cell cycle (Rider et al. 2003a).

\section{Indirect immunoperoxidase analysis}

Uterine tissue was removed under anesthesia and the uterine horns from OVX rats, those pretreated with progesterone for $72 \mathrm{~h}(0 \mathrm{hE})$, and those pretreated with progesterone and estradiol for $6 \mathrm{~h}(6 \mathrm{hE})$ were fixed in $4 \%$ paraformaldehyde and embedded in paraffin using methods standard in our laboratory (Rider et al. 2006). Sections $(\sim 8 \mu \mathrm{m})$ were cut on a microtome and placed on Superfrost Plus slides (Fisher Scientific, Hanover Park, IL, USA). Sections were treated in $10 \mathrm{mM}$ sodium citrate at $95^{\circ} \mathrm{C}$ for $5 \mathrm{~min}$ to unmask the antigens. To remove endogenous peroxidase activity, tissue sections were quenched in $0.3 \%$ hydrogen peroxide (Sigma-Aldrich) in methanol at $22^{\circ} \mathrm{C}$ for $30 \mathrm{~min}$. Samples were blocked for $18 \mathrm{~h}$ in a blocking buffer $(50 \mathrm{mM}$ Tris- $\mathrm{HCl}, \mathrm{pH} 7.4$, $150 \mathrm{mM} \mathrm{NaCl}$ ) containing $1 \%$ normal bovine serum. The slides were washed in phosphate-buffered saline (PBS) and reacted with WNT-specific antibodies $(15 \mu \mathrm{g} / \mathrm{mL})$ (WNT4, AF475 R\&D Systems; WNT5a AF645, R\&D Systems; WNT7a AF3008, R\&D Systems; WNT7b AF3460, R\&D Systems). To evaluate the specificity of the reaction, some sections were incubated without primary antibody. Sections were reacted with biotinylated affinity-purified species-specific secondary antibodies (Vector Laboratories) for $60 \mathrm{~min}$ at $22^{\circ} \mathrm{C}$. Slides were reacted with the Vectastain Elite $\mathrm{ABC}$ reagent (Vector Laboratories), washed in PBS, and reacted for $2 \mathrm{~min}$ with equal volumes of $1 \mu \mathrm{g} / \mathrm{mL}$ diaminobenzidine (Aldrich, Milwaukee, WI, USA) dissolved in $0.1 \mathrm{M}$ Tris- $\mathrm{HCl}$, $\mathrm{pH} 7.2$, and $0.1 \%(\mathrm{v} / \mathrm{v})$ hydrogen peroxide diluted in PBS. Slides were counterstained with $1 \%$ methyl green dye in deionized water. The slides were mounted using Permount. The uterine horns from at least three animals at each time point were examined. There was no brown reaction product in the absence of primary antibodies. Representative sections were photographed using an Olympus BX41 microscope equipped with a digital camera.

\section{RNA isolation}

Uterine horns were pooled from three sexually mature Sprague-Dawley rats after each treatment (OVX, 0hE, 6hE) and homogenized in $4 \mathrm{~mL}$ TRIzol reagent using a Virtis Tempest Blade-type homogenizer at high-speed setting (setting 6). The entire cell lysate solution was added to Phase lock Gel Heavy Eppendorf tubes and incubated for $5 \mathrm{~min}$ at $22^{\circ} \mathrm{C}$. Then, chloroform $(0.2 \mathrm{~mL})$ was added and the tubes were vigorously shaken for $15 \mathrm{~s}$. Samples were centrifuged at $12,000 \mathrm{~g}$ for $10 \mathrm{~min}$ at $4^{\circ} \mathrm{C}$. RNA was precipitated by adding muscle glycogen $(10 \mu \mathrm{g}$; Ambion) and $0.5 \mathrm{~mL}$ isopropyl alcohol. RNA concentration and purity were determined by absorbance (260/280 nm) using a spectrophotometer.

\section{Reverse transcription and polymerase chain amplification (RT-PCR)}

Complementary DNA (cDNA) was synthesized with 1-4 $\mu$ g RNA using a High Capacity cDNA Kit (Applied Biosystems). Semiquantitative PCR amplification using a Peltier Thermocycler (MJ Research, San Francisco, CA, USA) was employed to measure $W n t$ mRNAs. The primers for glyceraldehyde phosphate dehydrogenase have been reported: Gapdh sense (5'-GAG TCA ACG GAT TTG GTC GT-3'); Wnt4 sense (5'-TGT ACC TGG CCA AGC TGT CAT-3'); Wnt5a sense (5'-TCC TAT GAG AGC GCA CGC AT-3'); Wnt7a sense (5'-CAA GGC CAG TAC CAC TGG GA-3'); and Wnt7b sense (5'-ACC AAA ACT TGC

Published by Bioscientifica Ltd. 
TGG ACC AC-3') (Mohamed et al. 2004). Conditions for amplification were determined empirically. Templates were denatured at $94^{\circ} \mathrm{C} 1 \mathrm{~min}$, annealed between 60 and $62^{\circ} \mathrm{C} 1 \mathrm{~min}$, and elongated at $72^{\circ} \mathrm{C} 1 \mathrm{~min}$ for 35 cycles. Annealing temperatures varied slightly $\left(W n t 4=61^{\circ} \mathrm{C}\right.$, $W n t 5 a=60.5^{\circ} \mathrm{C}, W n t 7 a=60^{\circ} \mathrm{C}, W n t 7 b=62^{\circ} \mathrm{C}$ ). The PCR products $(20 \mu \mathrm{L})$ were electrophoresed on $2 \%$ agarose gels. Amplified bands were photographed and the amount of Wnt was measured by scanning densitometry. The optical density of the target gene was divided by the optical density of Gapdh amplified from the same template.

\section{Cell culture}

Isolation and characterization of the uterine stromal cell lines are described in detail elsewhere (Piva et al. 1996). Briefly, the stromal cell lines were isolated from sexually mature Sprague-Dawley rat uteri. The cells express mesenchymal markers and female sex steroid (estradiol and progesterone) receptors. Proliferation of stromal cells was blocked by progesterone receptor antagonism. The proliferative response to progesterone plus FGF was studied by flow cytometry (Rider et al. 1998) and the MTT assay (Piva et al. 1996). Entry into DNA replication was monitored using 3H thymidine (Rider et al. 1998) and BrdU incorporation (Rider et al. 2003a). In this study, cells from the same passage (UIII, passages 20-25) were used to determine the treatment effects within an experiment by propagating a sufficient number of cells for each experiment in medium 199 containing 10\% FBS. Uterine stromal cells were seeded $\left(1 \times 10^{4}\right.$ per well $)$ in 24-well plates and quiescence was induced by culture for $72 \mathrm{~h}$ in serum-free, phenol red-free Dulbecco's Modified Eagles' medium (Gibco) containing molecular cellular development biology (MCDB)-105 (Sigma-Aldrich) in a 3:1 mixture. The medium contained insulin $(5 \mu \mathrm{g} / \mathrm{mL})$ and other supplements as detailed elsewhere (Piva et al. 1996). Quiescent cells were stimulated to synchronously enter the cell cycle by adding progesterone $(1 \mu \mathrm{M})$ and FGF $(50 \mathrm{ng} / \mathrm{mL})$. These doses were previously determined to be optimal in dose-response studies (Piva et al. 1996). Some cells were treated with progesterone or FGF alone. Stromal cells were collected at various time points $(0-48 \mathrm{~h})$ after addition of mitogenic agents.

Total RNA and proteins were sequentially separated from the same stromal cell samples by column purification (Norgen Biotek, Thorold, ON, Canada). Briefly, RNA was bound to the column and the proteins were collected in the flow through. RNA was treated with DNase I and eluted from the column. The $\mathrm{pH}$ of the flow through was adjusted, the proteins were bound to the column, and the columns were washed. The proteins were eluted and stored at $-80^{\circ} \mathrm{C}$. Protein concentration was determined using the Bradford Reagent (Bio-Rad) and RNA concentration was measured by absorbance $(260 / 280 \mathrm{~nm})$ using a spectrophotometer.

\section{Western blots}

Uterine stromal cell extracts were heated at $95^{\circ} \mathrm{C}$ for $3 \mathrm{~min}$ in SDS-sample buffer, cooled to $22^{\circ} \mathrm{C}$, and the proteins were size fractioned by SDS-PAGE. Proteins were transferred to a nitrocellulose membrane using standard methods (Jones et al. 2000, Rider et al. 2003a). For the chemiluminescent detection, the nitrocellulose membranes were reacted with a WNT5A antibody $(1 \mu \mathrm{g} / \mathrm{mL} ; \mathrm{R} \& \mathrm{D})$ at $22^{\circ} \mathrm{C}$ for $60 \mathrm{~min}$. Some samples were treated identically except the membranes were reacted without the primary antibody (data not shown). The membranes were washed and incubated for $60 \mathrm{~min}$ with a species-specific horseradish peroxidase (HRP)-conjugated secondary antibody (1:50,000; Pierce Biotechnology). The blots were incubated with a SuperSignal West Femto Maximum Sensitivity Substrate (Pierce Biotechnology) for $5 \mathrm{~min}$. The blots were exposed on chemiluminescent film to visualize WNT5A protein. The size of the reactive proteins was determined from prestained molecular size standards (Bio-Rad). The blots were stripped and reacted with a $\beta$-actin antibody (AC-15, Sigma) to control for equal protein loading. Scanning densitometry of $\beta$-actin across treatment groups and assays indicated that the amount of protein did not vary more than $7 \%$, verifying its lack of response to treatments (Rider et al. 2006). The relative amount of WNT5A was measured by scanning densitometry. The optical density of WNT5A was divided by the optical density of $\beta$-actin in the same sample. Two independent experiments were performed.

\section{Wnt5a mRNA stability}

To determine the effects on mRNA stability, stromal cells were plated $\left(2 \times 10^{5}\right.$ cells per dish $)$ in serum-free medium for $72 \mathrm{~h}$ to induce quiescence. The cells were stimulated with progesterone, FGF, and progesterone plus FGF. Certain cultures contained a dose actinomycin D $(25 \mu \mathrm{g} / \mathrm{mL})$ to inhibit new RNA synthesis for 2,4 , and $6 \mathrm{~h}$ (Rider et al. 2003b). The stromal cells were collected in TRIzol and RNA was purified using the phase lock gel heavy tubes. The amount of Wnt5a mRNA was measured using semiquantitative PCR. The optical density of Wnt5a

Published by Bioscientifica Ltd 
was divided by the optical density of Gapdh amplified from the same template. Three independent assays were performed.

\section{Wnt5a gene knockdown}

Quiescent stromal cells were transfected with Wnt5a siRNA (5 nM; Silencer Select) and non-targeting siRNA ( $5 \mathrm{nM}$; Silencer Select) according to the manufacturer's protocol using lipid-mediated transfection (Lipofectamine RNAiMAX Transfection Reagent; Ambion, Life Technologies Corp) at $48 \mathrm{~h}$ of serum starvation. After $24 \mathrm{~h}$, the stromal cells were stimulated to synchronously enter the cell cycle by adding progesterone $(1 \mu \mathrm{M})$ and FGF (50 ng/mL). The proliferative response was measured using the MTT assay. Results were obtained from three experiments with six replicate wells in each.

Real-time PCR (Step-one; Applied Biosystems) was carried out according to the manufacturer's protocol. Templates of $W n t 5 a$ were quantified using a Taqman probe and Wnt5a primers (Rn01402000; Applied Biosystems) specific for the Wnt5a gene. A Taqman probe and Gapdh (Hs99999905; Applied Biosystems)-specific gene primers were used for the internal control. The average $\mathrm{Ct}$ of

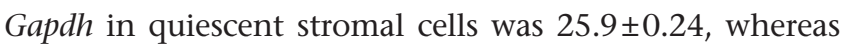
the average Ct of Gapdh in stimulated stromal cells was $25.8 \pm 0.29$, indicating no change in response to treatment. In each cycle, fluorescent signals for Wnt5a and Gapdh were collected from triplicate samples. The relative quantity (RQ value) was calculated and compared with cDNA synthesized from stromal cells stimulated to proliferate with progesterone plus FGF. Samples without template were included in triplicate on each plate as a negative control.

\section{Statistical analysis}

Differences between groups were analyzed using the nonparametric Mann-Whitney test. $P$ values less than 0.05 (two-sided) were considered statistically significant.

\section{Results}

\section{Wnt5a expression increases in response to progesterone pretreatment}

In order to determine the Wnt family members involved in stimulating uterine stromal cell proliferation and differentiation, expression of candidate Wht transcripts were measured in rat uterine RNA using semiquantitative
PCR (Fig. 1A). We compared Wnt expression in the uterine RNA isolated from OVX rats, those pretreated with progesterone $(72 \mathrm{~h}$ progesterone, $0 \mathrm{hE})$, and those pretreated with progesterone and estradiol for $6 \mathrm{~h}(6 \mathrm{hE})$ to stimulate stromal cell re-entry into the cell cycle. Of the four Wnt genes studied, expression of all increased numerically in response to progesterone alone, and then declined partially with the addition of estradiol.

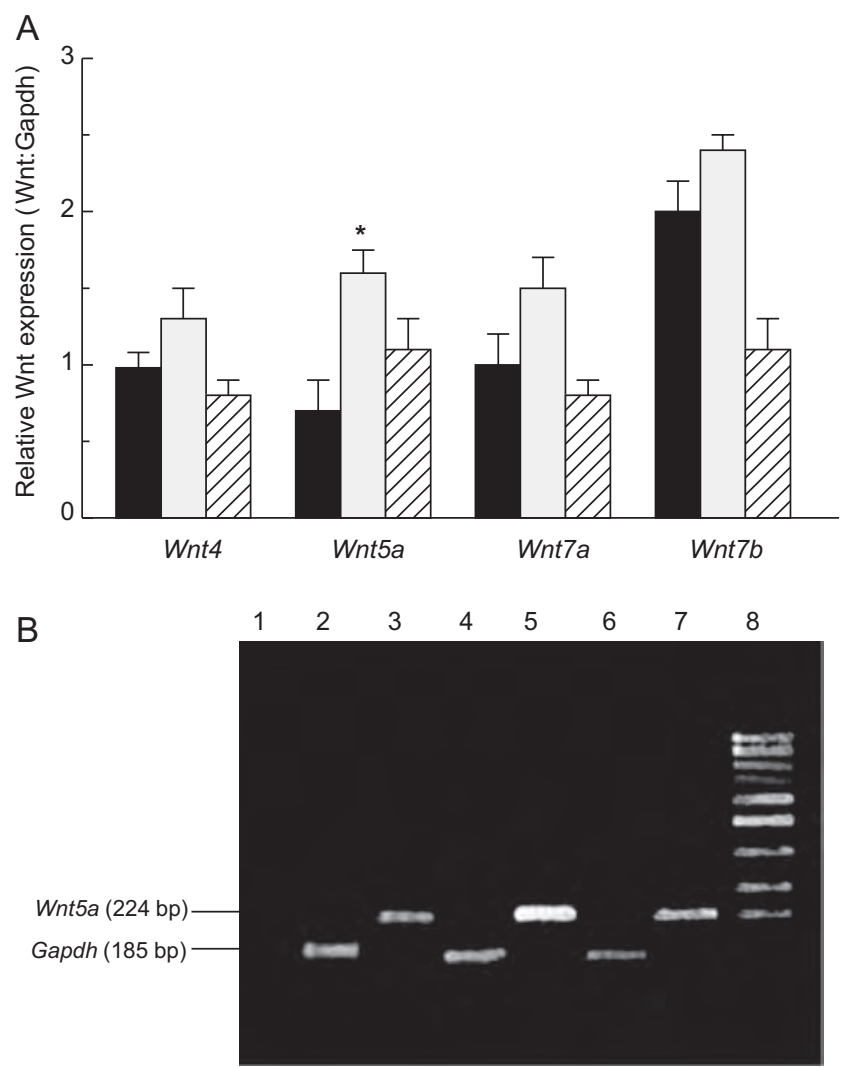

\section{Figure 1}

Progesterone increases $W n t$ transcript expression in rat uteri. RNA was isolated from OVX rat uteri, progesterone-pretreated uteri $(0 \mathrm{hE})$, and progesterone-pretreated uteri followed by a single injection of estradiol $(6 \mathrm{hE})$. The RNA was pooled from three rats at each treatment and converted into cDNA. Wnt target gene expression was compared with Gapdh in the same sample. (A) Quantitative assessment of the changes in the expression for four Wnt genes in response to progesterone pretreatment $(0 \mathrm{hE})$ and progesterone pretreatment with a single injection of estradiol (6 hE). The Wnt target genes were compared with Gapdh in the same sample. Data are mean values \pm S.E.M. from four replicates for each treatment group. Black boxes are data from OVX uteri, gray boxes are data from progesterone-pretreated uteri $(0 \mathrm{hE})$, and stippled boxes are data from progesterone-pretreated uteri given a single injection of estradiol ( $6 \mathrm{hE}) .{ }^{*} P<.05$, Mann-Whitney $U$ test. (B) A representative gel of the PCR products using the Wnt5a target gene primers and Gapdh gene primers. Lane 1, no template, negative control; lane 2, OVX uteri with Gapdh primers; Lane 3, OVX uteri with Wnt5a primers; lane 4; $0 \mathrm{hE}$ with Gapdh primers; lane 5, $0 \mathrm{hE}$ with Wnt5a primers; lane 6, $6 \mathrm{hE}$ with Gapdh primers; lane 7, 6 hE with Wnt5a primers; lane 8 , molecular size markers.

Published by Bioscientifica Ltd. 
The magnitude of change was significantly greater $(P<0.05)$ for $W n t 5 a$ in response to progesterone compared with the amount in OVX rat uteri. A representative gel of PCR products from rat uteri shows the increase in Wnt5a transcripts in response to progesterone alone (Fig. 1B).

\section{Changes in the spatial distribution of Wnt proteins in response to steroid hormones}

The cell-specific distribution of the four WNT proteins was compared among rat uteri in the absence of hormone (OVX), progesterone pretreatment $(0 \mathrm{hE})$, and progesterone pretreatment followed by estradiol exposure for $6 \mathrm{~h}(6 \mathrm{hE})$. In OVX rat uteri, WNT4 protein was evident in the luminal and glandular epithelia and that cell-specific distribution remained after rats were treated with progesterone (Fig. 2, $0 \mathrm{hE}$ ). Progesterone pretreatment followed by $6 \mathrm{~h}$ of estradiol stimulated WNT4 expression in the uterine stromal cells and expression was maintained in the epithelial cells (Fig. 2,
$6 \mathrm{hE})$. WNT5A protein was expressed in the luminal and glandular epithelial cells of OVX rat uteri (Fig. 2). In response to progesterone pretreatment, WNT5A protein was evident particularly in the periluminal uterine stromal cells as shown by arrowheads in Fig. 2, $0 \mathrm{hE}$. Expression was maintained in the epithelium. In response to progesterone pretreatment followed by estradiol administration, WNT5A was expressed in the epithelial and stromal cells (Fig. 2, 6hE). WNT7A was expressed in the epithelial cells of OVX rat uteri (Fig. 2, OVX). The cell-specific expression did not change in response to progesterone pretreatment (Fig. 2, 0 hE). However, in response to progesterone pretreatment followed by exposure to estradiol, WNT7A was detected in some stromal cells as well as the epithelial cells (Fig. 2, 6hE). WNT7B was expressed in the luminal and glandular epithelial cells of uteri from OVX rats (Fig. 2, OVX). Progesterone pretreatment did not affect the cellular distribution of WNT7B protein (Fig. 2, $0 \mathrm{hE}$ ). However, the glandular expression was strong in progesterone-pretreated uteri $(0 \mathrm{hE})$. In uteri from rats
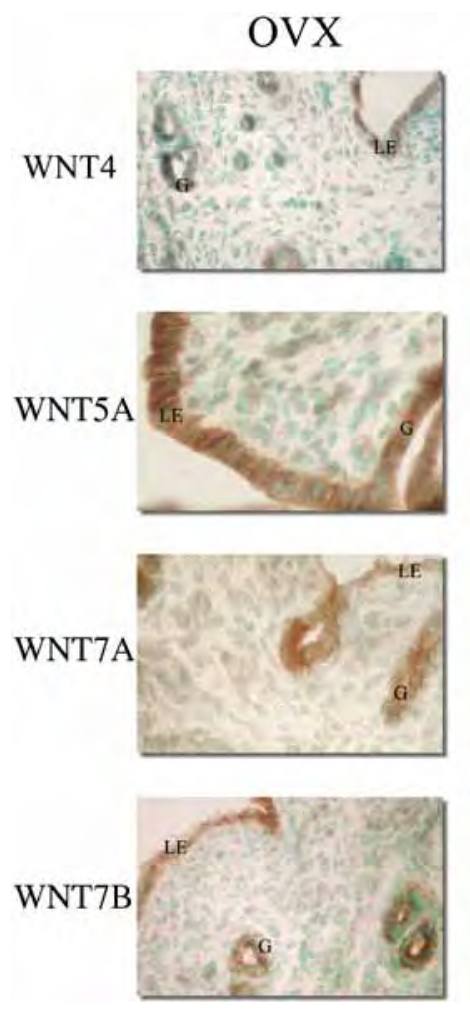

$0 \mathrm{hE}$
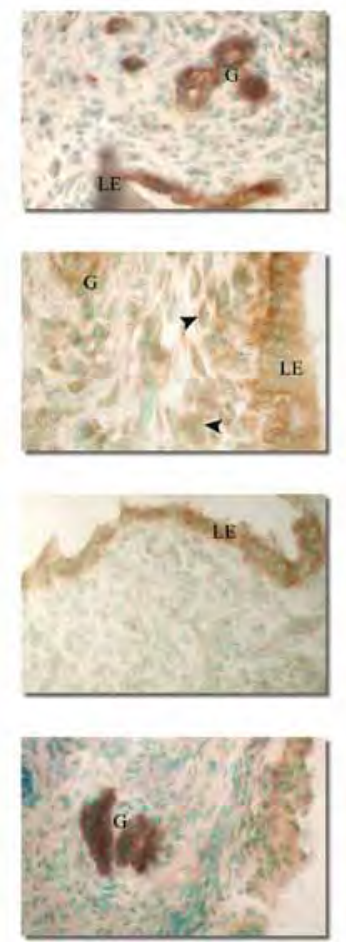

$6 \mathrm{hE}$
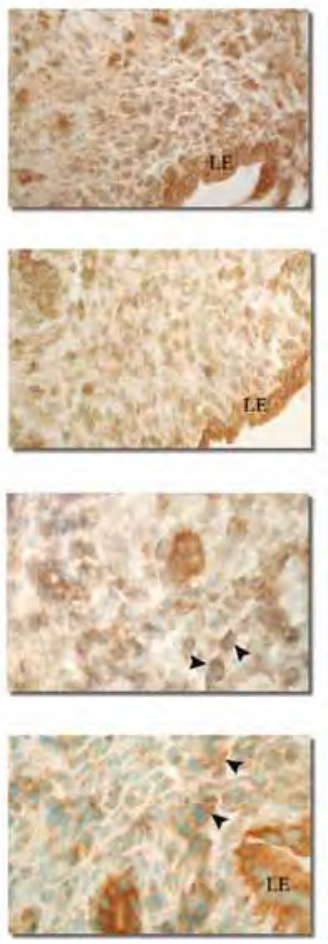

CTRL
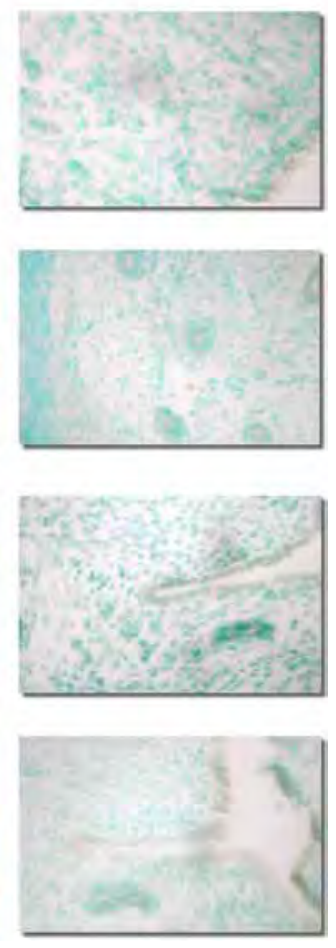

\section{Figure 2}

The spatial distribution of WNT proteins changes in response to sex steroids. Paraffin-embedded rat uteri were sectioned as detailed in the text and the cell-specific distribution of WNT proteins was assessed using standard immunocytochemistry. Ovariectomized=OVX, 0 hE = progesterone pretreated, $6 \mathrm{hE}=$ progesterone pretreated plus estradiol for $6 \mathrm{~h}, \mathrm{CTRL}$, control sections counterstained with methyl green. LE, luminal epithelium; G, glandular epithelium. Arrowheads indicate positive cells in the stroma. Original magnifications: 400 and 1000x.

http://joe.endocrinology-journals.org DOI: 10.1530/JOE-15-0523
๑ 2016 Society for Endocrinology Printed in Great Britain
Published by Bioscientifica Ltd. 
pretreated with progesterone and estradiol, WNT7B was detected in epithelial cells and in some stromal cells (Fig. 2, 6hE).

Taken together, the results indicated that progesterone pretreatment not only enhanced Wnt5a transcript expression but that WNT5A protein was evident in the periluminal stromal cells, which proliferate and differentiate into decidual cells.

\section{Progesterone increases WNT5a expression in proliferating uterine stromal cell lines}

To extend this observation and gain further insight into the consequence of progesterone regulation of WNT5A expression, a well-characterized rat uterine stromal cell line was utilized. Cultured uterine stromal cells (UIII) were stimulated with progesterone $(1 \mu \mathrm{M})$ and FGF $(50 \mathrm{ng} / \mathrm{mL})$ to induce proliferation. Proliferation increased significantly $(P<0.05)$ as expected (Fig. 3A) in response to progesterone plus FGF. No increase in cell number was detected in stromal cells stimulated with progesterone alone or FGF alone.

To determine whether WNT5A was a progesterone target in proliferating stromal cells, total RNA and proteins were sequentially isolated from stromal cells cultured with progesterone and FGF at various times $(0,6,12$, and $24 \mathrm{~h})$. WNT5A was detected by western blotting in all treatment groups (Fig. 3B). WNT5A increased approximately two-fold in all stromal cells at $6 \mathrm{~h}$ post stimulation (Fig. 3C). WNT5A protein was numerically maximal in response to progesterone (triangle) at $12 \mathrm{~h}$ post progesterone treatment. At $12 \mathrm{~h}$ post stimulation with progesterone plus FGF (diamond) and FGF (box ) alone, the amount of WNT5A declined slightly from the amount measured at $6 \mathrm{~h}$ post stimulation.

Surprisingly, semiquantitative PCR analysis of Wnt5a transcripts after treatment of cells with proliferative agents (progesterone plus FGF) revealed no changes in the amount of Wnt5a mRNA at these same time points (data not shown). To investigate whether progesterone and FGF stabilized Wnt5a mRNA, uterine stromal cells were stimulated with progesterone alone, FGF alone, and progesterone plus FGF in the presence of actinomycin D to inhibit new mRNA synthesis (Fig. 4). The relative amount of Wnt5a transcripts increased numerically in response to progesterone alone after $6 \mathrm{~h}$ of inhibition. Progesterone plus FGF increased $(P<0.05)$ Wnt $5 a$ transcripts at 4 and $6 \mathrm{~h}$ of culture in actinomycin $\mathrm{D}$. Together, the results suggest that progesterone plus FGF increased Wnt5a expression, in part, by stabilizing its mRNA.
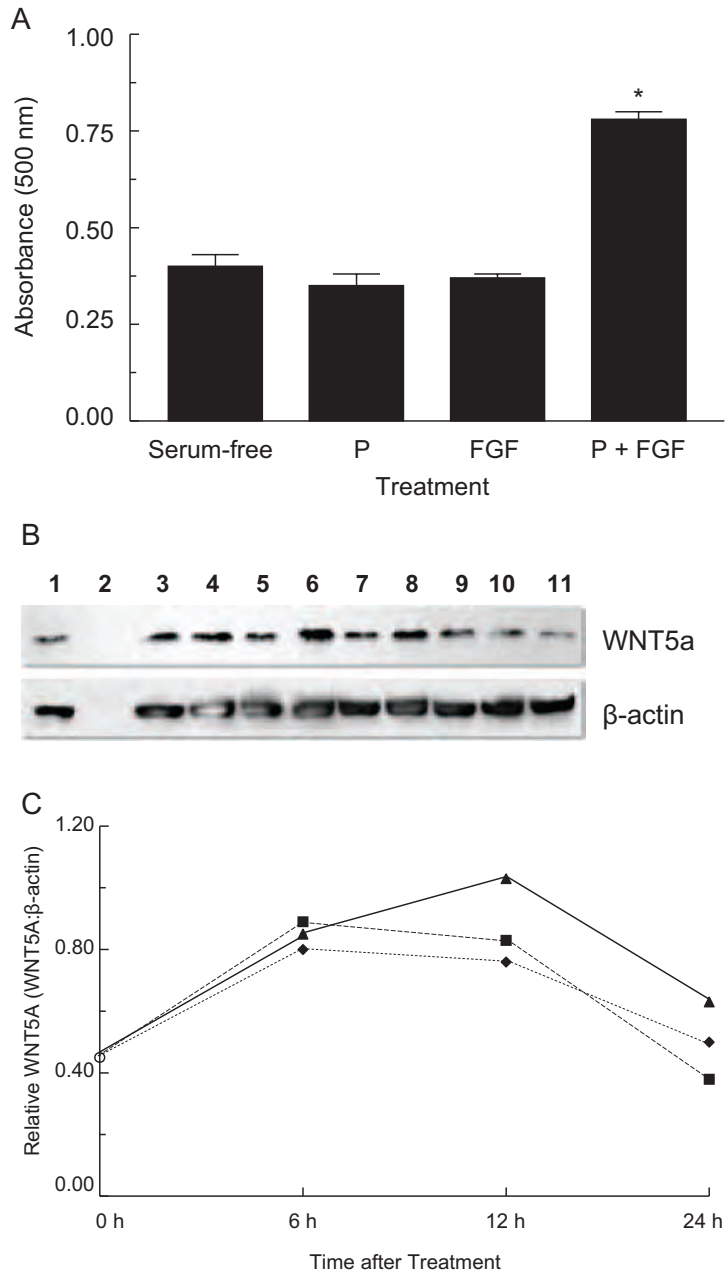

Figure 3

Progesterone plus FGF increase proliferation and WNT5A expression in uterine stromal cell lines in culture. (A) Quiescent uterine stromal cells (UIII, passage 20) were stimulated with progesterone, FGF, and progesterone plus FGF. The proliferative response was measured $48 \mathrm{~h}$ after stimulation using the MTT reagent. Data are mean values \pm S.E.M. from three experiments with three replicates in each experiment. $* P<0.05$, Mann-Whitney $U$ test. (B) Proliferating stromal cells were collected at various time points after stimulation, and the expression of WNT5A protein was measured by scanning densitometry of western blots. Representative western blot of WNT5A expression in uterine stromal cells stimulated with progesterone, FGF, and progesterone plus FGF. Lane 1, proteins from rat uteri treated with progesterone for 3 days (positive control); lane 2, no extract (negative control); lane 3, uterine stromal cells treated with progesterone for $6 \mathrm{~h}$; lane 4, uterine stromal cells treated with FGF for 6 h; lane 5 , uterine stromal cells treated with progesterone plus FGF for $6 \mathrm{~h}$; lane 6 , uterine stromal cells treated with progesterone for $12 \mathrm{~h}$; lane 7 , uterine stromal cells treated with FGF for $12 \mathrm{~h}$; lane 8 , uterine stromal cells treated with progesterone plus FGF for $12 \mathrm{~h}$; lane 9, uterine stromal cells treated with progesterone for $24 \mathrm{~h}$; lane 10, uterine stromal cells treated with FGF for $24 \mathrm{~h}$; lane 11, uterine stromal cells treated with progesterone plus FGF for $24 \mathrm{~h}$. (C) Quantitative changes in WNT5A expression in uterine stromal cells stimulated with proliferative agents. The amount of WNT5A was adjusted to $\beta$-actin in the same sample. WNT5A numerically increased in response to progesterone (triangle), FGF (diamond), and progesterone plus FGF (box) with approximately a two-fold increase at 6 and $12 \mathrm{~h}$ in response to progesterone alone. Data are mean values from two independent experiments.

Published by Bioscientifica Ltd. 


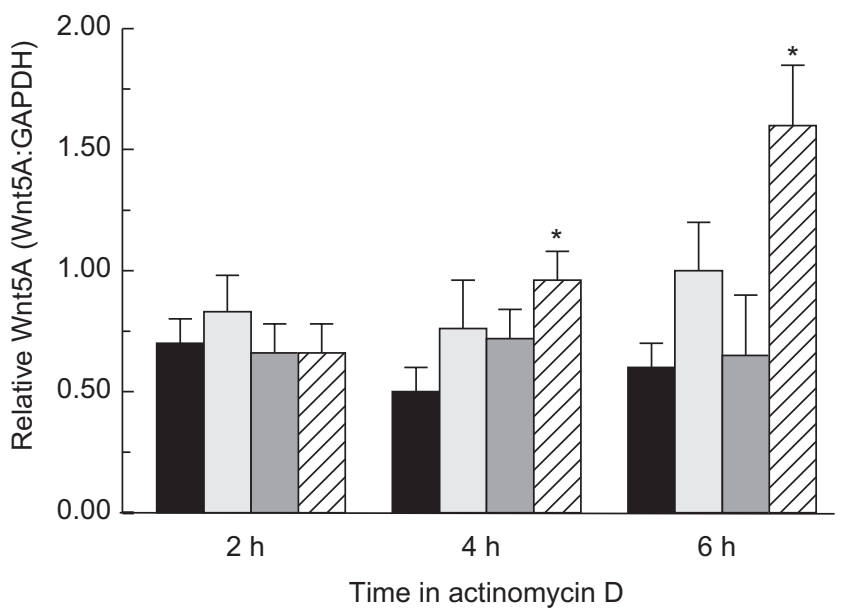

Figure 4

Progesterone plus FGF stabilize Wnt5a mRNA. Quiescent uterine stromal cell lines (UIII, passage 23) were stimulated with progesterone, FGF, and progesterone plus FGF in medium containing actinomycin $D$ to inhibit new mRNA synthesis. The amount of Wnt5a mRNA was measured using semiquantitative PCR as detailed in the text. Data are mean values \pm S.E.M. from three independent experiments. Black boxes, serum-free medium; white boxes, progesterone alone; gray boxes, FGF alone; stippled boxes progesterone plus FGF. ${ }^{*} P<0.05$, Mann-Whitney $\mathrm{U}$ test.

\section{WNT5a is essential for stromal cell proliferation}

In response to progesterone and estradiol, uterine stromal cells proliferate and differentiate into the decidua. Previous studies from our laboratory (Piva

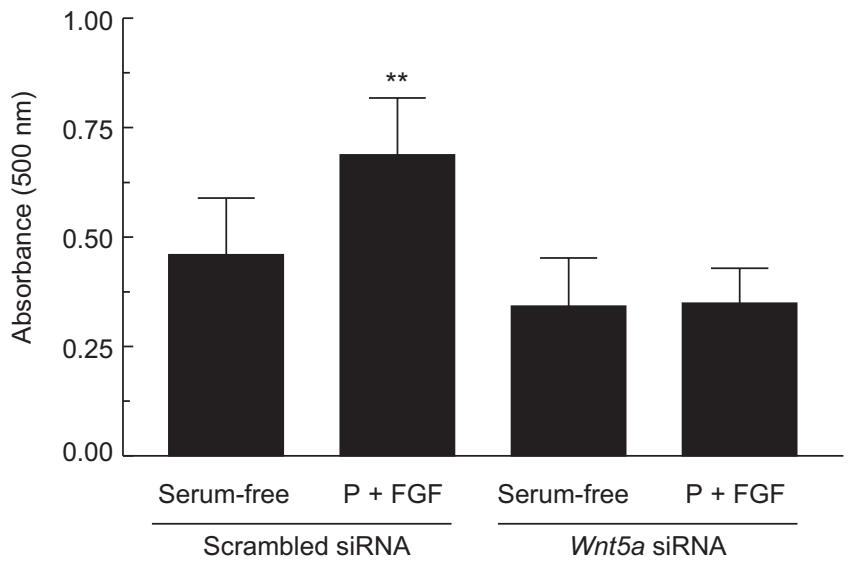

Figure 5

Inhibition of Wnt5a blocks progesterone-induced stromal cell proliferation. Quiescent uterine stromal cells (UIII) were transfected with siRNA $24 \mathrm{~h}$ before stimulation. Transfected stromal cells were stimulated with progesterone plus FGF to induce proliferation. The cells were collected at $48 \mathrm{~h}$ after addition of mitogenic agents. Proliferation was assessed using the MTT assay. Progesterone plus FGF stimulated stromal cell proliferation significantly in stromal cells transfected with scrambled siRNA but not with Wnt5a siRNA. ${ }^{* *} P<0.004$, Mann-Whitney $U$ test. Data are mean values \pm S.D. of three independent assays with six replicates in each experiment. et al. 1996) and the current results (Fig. 3A) indicate that progesterone plus FGF stimulate stromal cell lines to proliferate. To test whether WNT5A was a target of progesterone-mediated stromal cell proliferation, stromal cells were stimulated with progesterone and FGF (Fig. 5). Some cells were transfected with scrambled siRNA, whereas other cells received Wnt5a-specific siRNA. The proliferative response was assessed using the MTT assay (Fig. 5). Progesterone plus FGF increased stromal cell number in the presence of scrambled siRNA $(P<0.004$, Mann-Whitney U test). For cells transfected with Wnt5a siRNA, there was no effect of progesterone plus FGF on cell number. Real-time PCR revealed Wnt5a mRNA only in stimulated stromal cells transfected with scrambled siRNA. Wnt5a mRNA was not detected in quiescent (serum-free) stromal cells or in cells stimulated after transfection with $W n t 5 a$ siRNA.

\section{Discussion}

The purpose of this study is to gain additional insight into the signaling mechanisms regulating the progesteronedependent switch in proliferation from epithelium to stroma. Attention was focused on uterine stromal cells because these cells differentiate into the decidua and interface with the fetal placenta. All of the four genes studied exhibited an increase in transcript expression in response to progesterone alone. The expression of WNT5A protein in the endometrium was restricted to the epithelial cells before progesterone treatment. Progesterone treatment specifically induced WNT5A in the uterine stromal cells. To investigate the mechanism(s) underlying the proliferative switch from epithelium to stroma, well-characterized uterine stromal cell lines were utilized. Progesterone plus FGF stimulated stromal cell proliferation. Proliferation was accompanied by increased WNT5A protein but not mRNA. Inhibition of new mRNA synthesis in stromal cells stimulated to proliferate revealed an increase in $W n t 5 a$ transcripts in response to progesterone that was further enhanced by progesterone plus FGF. These results indicate that progesterone plus FGF increase WNT5A expression in proliferating uterine stromal cells in part by stabilizing Wnt5a mRNA. Moreover, knockdown of WNT5A blocked stromal cell proliferation, indicating the importance of WNT5A signaling in regulating the uterine stromal cell cycle.

Stromal cell proliferation and differentiation are required to alter the uterus to a receptive state for embryo implantation (Dey et al. 2004, Ramathal et al. 2010).

Published by Bioscientifica Ltd. 
Proliferation and differentiation are largely under the control of female sex steroids, estradiol and progesterone, acting through their cognate receptors (Lydon et al. 1995, Franco et al. 2012, Pawar et al. 2014, Thouas et al. 2015). Evidence suggests that these hormones act in a temporal and spatially ordered fashion regulating cell-cell communication between epithelial and stromal compartments and through paracrine actions within compartments. In rodents, estradiol stimulates proliferation of uterine epithelial cells (Martin \& Finn 1968). At day 4 of pregnancy in the rat, proliferation is redirected to stromal cells by progesterone inhibition of epithelial cell proliferation (Rider \& Psychoyos 1994) and down-regulation of stromal cell GSK-3 $\beta$ (Rider et al. 2006). Administration of the progesterone receptor antagonist, RU486, at days 1 and 2 post-coitum stimulated epithelial cell proliferation in rat uteri; however, the progesterone-dependent proliferative switch to stromal cells was blocked (Rider \& Psychoyos 1994). More recently, tissue-specific knockout of the progesterone receptor in the epithelial cells of mouse uteri allowed for the continued proliferation of epithelial cells in the absence of progesterone receptor action (Franco et al. 2012). In contrast to the RU486 blockade of progesterone receptor action in both compartments, however, the proliferative switch to stroma occurred normally in the absence of epithelial progesterone receptors, suggesting that progesterone-dependent proliferation in the stroma is controlled by stromal not epithelial cell progesterone receptors.

The canonical WNT5A signaling pathway stabilizes $\beta$-catenin. As $\beta$-catenin accumulates, it translocates to the nucleus and activates cell cycle regulators such as cyclin D and c-myc (Zimmerman et al. 2012). Progesterone stimulates the expression of WNT5A and the accumulation of $\beta$-catenin in rat uterine stromal cells consistent with canonical WNT5A signaling. Previously, we found that progesterone pretreatment of rat uteri increases the expression of cyclins D1 and D3, both Wnt signaling targets (Rider et al. 2006). The current results are consistent with the idea that WNT5A, acting through the canonical pathway, is an early and essential signal in the progesterone-dependent proliferative switch from epithelia to stroma because blockade of this pathway inhibits stromal cell proliferation.

Non-canonical WNT5A signaling regulates cell adhesion and cell movement and provides positional information to cells (Katoh \& Katoh 2007, Endo et al. 2015). Wnt signaling facilitates changes in the cytoskeleton and junctional complexes among cells (Zimmerman et al.
2012). It is interesting to note that conditional deletion of the Cx34 (Gjb4) gap junction protein gene does not prevent stromal cells from proliferating; however, the cells do not differentiate (Laws et al. 2008). The results from this study show an essential role for WNT5A in stromal cell proliferation. Other studies (Cha et al. 2014) suggest that WNT5A acts through non-canonical signal transduction to promote decidualization. It is possible that non-canonical signaling shuts off the progesterone$\beta$-catenin-TCF pathway and activates polar cell migration (Minami et al. 2010) necessary for decidualization. It is now important to determine whether stromal cell proliferation and differentiation are coupled through WNT5A; however, the signaling pathway for proliferation is different than that for differentiation.

There is ample evidence that epithelial-stromal cross talk is essential during the initial implantation reaction (Mericskay et al. 2004, Nallasamy et al. 2012). The spatial distribution of the four Wnt genes in OVX rat uteri revealed hormone-independent expression in the glandular and luminal epithelia. WNT7B expression appeared to increase in the glandular epithelia in response to progesterone alone; however, the fold-change in expression was not measured. In the adult mouse uterus, WNT7B expression increases in response to estradiol (Hayashi et al. 2009). The function of $W n t 7 b$ in the adult uterus, however, is not known.

Progesterone plus estradiol decreased transcript expression of the four Wnt genes studied. The spatial distribution of WNT proteins, however, changed in response to estradiol, and all four WNT proteins were expressed in the progesterone-pretreated stromal cells in response to estradiol. It is notable that WNT5A was the only protein expressed in the progesterone-pretreated stromal cells. Of additional interest was the strong expression of WNT4 in the stromal cells of rat uteri following $6 \mathrm{~h}$ of estradiol injection. Culture of primary human endometrial cells with cyclic AMP and steroid hormones stimulate their differentiation as assessed by expression of the decidual cell markers prolactin and IGFBP (Li et al. 2013). WNT4/ $\beta$-catenin signaling was essential for differentiation as blockade of either WNT4 or $\beta$-catenin reduced the expression of decidual cell markers. The increased expression of several WNT proteins in the stroma in response to progesterone and estradiol suggests that a number of different Wnt genes are important for uterine stromal cell differentiation. Our results suggest that $W n t 5 a$ is an early signaling event in the stroma that is essential for stromal cell proliferation. Understanding the spatial and temporal

Published by Bioscientifica Ltd. 
activation of Wnt signaling in response to sex steroids will improve understanding of endocrine control of cell proliferation and differentiation.

\section{Declaration of interest}

The authors declare that there is no conflict of interest that could be perceived as prejudicing the impartiality of the research reported.

\section{Funding}

The research was supported in part by the NIH (National Center for Research Resources (SP20RR016475) and the National Institute of General Medical Sciences (8P20GM103418)).

\section{Author contribution statement}

$V R$ wrote the paper, trained the students, and designed the experiments. $\mathrm{A} T$ and $\mathrm{Z} K$ carried out the $W n t$ localization and expression studies. A B conducted the siRNA experiments. S F and $J \mathrm{~W}$ are responsible for the western blot analyses and PCR analyses of Wnt5a in cultured stromal cells. $\mathrm{B} K$ conducted the statistical analysis and participated in the experimental design. All authors have reviewed this manuscript before its submission.

\section{Acknowledgments}

The authors are grateful to Malcolm Turner for assistance with the figures.

\section{References}

Bell SC 1983 Decidualization: regional differentiation and associated function. Oxford Reviews in Reproductive Biology 5 220-271.

Butt AJ, Caldon CE, McNeil CM, Swarbrick A, Musgrove EA \& Sutherland RL 2008 Cell cycle machinery: links with genesis and treatment of breast cancer. Advances in Experimental Medicine and Biology 630 189-205. (doi:10.1007/978-0-387-78818-0)

Cha J, Bartos A, Park C, Sun X, Li Y, Cha, S-W, Ajima R, Hsin-Yi HH, Yamaguchi TP \& Dey SK 2014 Appropriate crypt formation in the uterus for embryo homing and implantation requires Wnt5a-ROR signaling. Cell Reports 8 382-392. (doi:10.1016/j. celrep.2014.06.027)

Daniels DL \& Weis WI 2005 -catenin directly displaces Groucho/TLE repressors from Tcf/Lef in Wnt-mediated transcription activation. Nature Structural Molecular Biology 12 364-371. (doi:10.1038/ nsmb912)

Dey SK, Lim H, Das SK, Reese J, Paria BC, Daikoku T \& Wang H 2004 Molecular cues to implantation. Endocrine Reviews 25 341-373. (doi:10.1210/er.2003-0020)

Dunlap KA, Filant J, Hayashi K, Rucker EB III, Song G, Deng JM, Behringer RR, DeMayo FJ, Lydon J, Jeong J-W, et al. 2011 Postnatal deletion of Wnt7a inhibits uterine gland morphogenesis and compromises adult fertility in mice. Biology of Reproduction $\mathbf{8 5}$ 386-396. (doi:10.1095/biolreprod.111.091769)

Endo M, Nishita M, Fujii M \& Minami Y 2015 Insight into the role of Wnt5a-induced signaling in normal and cancer cells. International Review of Cell and Molecular Biology 314 117-148. (doi:10.1016/ bs.ircmb.2014.10.003)
Finn CA \& Martin L 1967 Patterns of cell division in the mouse uterus during early pregnancy. Journal of Endocrinology 39 593-597. (doi:10.1677/joe.0.0390593)

Franco HL, Dai D, Lee KY, Rubel CA, Roop D, Boerboom D, Jeong J-W, Lydon JP, Bagchi IC, Bagchi MK, et al. 2011 WNT4 is a key regulator of normal postnatal uterine development and progesterone signaling during embryo implantation and decidualization in the mouse. FASEB Journal 25 1176-1187. (doi:10.1096/fj.10-175349)

Franco HL, Rubel CA, Large MJ, Wetendorf M, Fernandez-Valdivia R, Jeong JW, Spencer TE, Behringer RR, Lydon JP \& DeMayo FJ 2012 Epithelial progesterone receptor exhibits pleiotropic roles in uterine development and function. FASEB Journal 26 1218-1227. (doi:10.1096/fj.11-193334)

Fritz R, Jain C \& Armant RD 2014 Cell signaling in trophoblast-uterine communication. International Journal of Developmental Biology $\mathbf{5 8}$ 261-271. (doi:10.1387/ijdb.140011da)

Hayashi K, Erikson DW, Tilford SA, Bany BM, Maclean JA, Rucker EB, Johnson GA \& Spencer TE 2009 Wnt genes in the mouse uterus: potential regulation of implantation. Biology of Reproduction $\mathbf{8 0}$ 989-1000. (doi:10.1095/biolreprod.108.075416)

Hayashi K, Yoshioka S, Reardon SN, Rucker EB III, Spencer TE, DeMayo FJ, Lydon JP \& MacLean JA II 2011 WNTs in the neonatal mouse uterus: potential regulation of endometrial gland development. Biology of Reproduction 84 308-319. (doi:10.1095/ biolreprod.110.088161)

Jeong J-W, Lee HS, Franco HL, Broaddus RR, Taketo MM, Tsai SY, Lydon JP $\&$ DeMayo FJ $2009 \beta$-catenin mediates glandular formation and dysregulation of $\beta$-catenin induces hyperplasia formation in the murine uterus. Oncogene 28 31-40. (doi:10.1038/onc.2008.363)

Jones SR, Kimler BF, Justice WM \& Rider V 2000 Transit of normal rat uterine stromal cells through G1 phase of the cell cycle requires progesterone-growth factor interaction. Endocrinology 141 637-648. (doi:10.1210/endo.141.2.7332)

Katoh M \& Katoh M 2007 STAT3-induced WNT5A signaling loop in embryonic stem cells, adult normal tissues, chronic persistent inflammation, rheumatoid arthritis and cancer (Review). International Journal of Molecular Medicine 19 273-278.

Laws MJ, Taylor RN, Sidell N, DeMayo FJ, Lydon JP, Gutsterin DE, Bagchi MK \& Bagchi IC 2008 Gap junction communication between uterine stromal cells plays a critical role in pregnancy-associate neovascularization and embryo survival. Development 135 2659-2668. (doi:10.1242/dev.019810)

Li Q, Kannan A, Das A, DeMayo FJ, Hornsby PJ, Young SL, Taylor RN, Bagchi MK \& Bagchi IC 2013 WNT4 acts downstream of BMP2 and function via $\beta$-catenin signaling pathway to regulate human endometrial stromal cell differentiation. Endocrinology 154 446-457. (doi:10.1210/en.2012-1585)

Lydon JP, DeMayo FJ, Funk CR, Mani SK, Hughes AR, Montgomery CA Jr, Shyamala G, Conneely OM \& O'Malley BW 1995 Mice lacking progesterone receptor exhibit pleiotropic reproductive abnormalities. Genes and Development 9 2266-2278. (doi:10.1101/gad.9.18.2266)

Martin L \& Finn CA 1968 Hormonal regulation of cell division in epithelial and connective tissues of the mouse uterus. Journal of Endocrinology 41 363-371. (doi:10.1677/joe.0.0410363)

Mericskay M, Kitajewski J \& Sassoon D 2004 Wnt5a is required for proper epithelial-mesenchymal interactions in the uterus. Development 131 2061-2072. (doi:10.1242/dev.01090)

Miller C \& Sassoon DA 1998 Wnt-7a maintains appropriate uterine patterning during the development of the mouse female reproductive tract. Development 125 3201-3211.

Minami Y, Oishi I, Edno M \& Nishita M 2010 Ror-family receptor tyrosine kinases in noncanonical Wnt signaling: their implication in developmental morphogenesis and human diseases. Developmental Dynamics 239 1-15. (doi:10.1002/dvdy.21991)

Mohamed OA, Dufort D \& Clarke HJ 2004 Expression and estradiol regulation of Wnt genes in the mouse blastocyst identify a candidate

Published by Bioscientifica Ltd. 
pathway for embryo-maternal signaling at implantation. Biology of Reproduction 71 417-424. (doi:10.1095/biolreprod.103.025692)

Mohamed OA, Jonnaert M, Labelle-Dumais C, Kuroda K \& Clarke HJ 2005 Uterine Wnt/beta catenin signaling is required for implantation. PNAS 102 8579-8584. (doi:10.1073/pnas.0500612102)

Nallasamy S, Li Q, Magchi MK \& Bagchi IC 2012 Msx homeobox genes critically regulate embryo implantation by controlling paracrine signaling between uterine stroma and epithelium. PLoS Genetics 8 1-13. (doi:10.1371/journal.pgen.1002500)

Parr BA \& McMahon AP 1998 Sexually dimorphic development of the mammalian reproductive tract requires Wnt-7a. Nature 395 707-710. (doi:10.1038/27221)

Paul S \& Dey A 2008 Wnt signaling and cancer development: therapeutic implication. Neoplasma 55 165-176.

Pawar S, Hantak AM, Bagchi IC \& Bagchi MK 2014 Minireview: steroidregulated paracrine mechanisms controlling implantation. Molecular Endocrinology 28 1408-1422. (doi:10.1210/me.2014-1074)

Philibert P, Biason-Lauber A, Rouzier R, Pienkowski C, Paris F, Konrad D, Schoenle E \& Sultan C 2008 Identification and functional analysis of a new WNT4 gene mutation among 28 adolescent girls with primary amenorrhea and müllerian duct abnormalities: a French collaborative study. Journal of Clinical Endocrinology and Metabolism 93 895-900. (doi:10.1210/jc.2007-2023)

Piva M, Flieger O \& Rider V 1996 Growth factor control of cultured rat uterine stromal cell proliferation is progesterone dependent. Biology of Reproduction 55 1333-1342. (doi:10.1095/biolreprod55.6.1333)

Ramathal CY, Bagchi IC, Taylor RN \& Bagchi MK 2010 Endometrial decidualization: of mice and men. Seminars in Reproductive Medicine $\mathbf{2 8}$ 17-26. (doi:10.1055/s-0029-1242989)

Rider V \& Psychoyos A 1994 Inhibition of progesterone receptor function results in loss of basic fibroblast growth factor expression and stromal cell proliferation during uterine remodeling in the pregnant rat. Journal of Endocrinology 36 239-248. (doi:10.1677/joe.0.1400239)

Rider V, Kimler BF \& Justice WM 1998 Progesterone-growth factor interactions in uterine stromal cells. Biology of Reproduction $\mathbf{6 6}$ 188-193.

Rider V, Thomson E \& Seifert C 2003a Transit of rat uterine stromal cells through G1 phase of the cell cycle requires temporal and cell-specific hormone-dependent changes on cell cycle regulators. Endocrinology 144 5450-5458.

Rider V, Keltner S \& Abou NI 2003b Increased estrogen-dependent expression of calcineurin in female SLE T cells is regulated by multiple mechanisms. Journal of Gender Specific Medicine 6 14-21.

Rider V, Isuzugawa K, Twarog M, Jones S, Cameron B, Imakawa K \& Fang J 2006 Progesterone initiates Wnt-beta-catenin signaling but estradiol is required for nuclear activation and synchronous proliferation of rat uterine stromal cells. Journal of Endocrinology 191 537-548. (doi:10.1677/joe.1.07030)

Sonderegger S, Pollheimer J \& Knofler M 2010 Wnt signaling in implantation, decidualisation and placental differentiation-review. Placenta 31 839-847. (doi:10.1016/j.placenta.2010.07.011)

Tepekoy F, Akkoyunlu G \& Demir R 2015 The role of Wnt signaling members in the uterus and embryo during pre-implantation and implantation. Journal of Assisted Reproduction and Genetics 32 337-346. (doi:10.1007/s10815-014-0409-7)

Thouas GA, Dominguez F, Green MP, Vilella F, Simon C \& Gardner DK 2015 Soluble ligands and their receptors in human embryo development and implantation. Endocrine Reviews 36 92-130. (doi:10.1210/er.2014-1046)

Vainio S, Heikkila M, Kispert A, Chin N \& McMahon AP 1999 Female development in mammals is regulated by Wnt- 4 signalling. Nature 397 707-710. (doi:10.1038/17820)

Wang Q, Lu J, Zhang S, Wang S, Wang W, Wang B, Wang F, Chen Q, Duan E, Leitges M, et al. 2013 Wnt6 is essential for stromal cell proliferation during decidualization in mice. Biology of Reproduction 88 1-9. (doi:10.1095/biolreprod.112.105957)

Willert K \& Jones KA 2006 Wnt signaling: is the party in the nucleus? Genes \& Development 20 1394-1404.

Yao MW, Lim H, Schust DJ, Choe SE, Farago A, Ding Y, Michaud S, Church GM \& Maas RL 2003 Gene expression profiling reveals progesterone-mediated cell cycle and immunoregulatory roles of Hoxa-10 in the preimplantation uterus. Molecular Endocrinology 17 610-627. (doi:10.1210/me.2002-0290)

Zimmerman ZF, Moon RT \& Chien AJ 2012 Targeting Wnt pathways in disease. Cold Spring Harbor Perspectives in Biology 4 1-24. (doi:10.1101/ cshperspect.a008086)

Received in final form 15 February 2016

Accepted 14 March 2016

Accepted Preprint published online 14 March 2016
๑) 2016 Society for Endocrinology Printed in Great Britain 